\title{
KONSTRUKSI PERLINDUNGAN HUKUM DEBITUR DALAM PENYELESAIAN KREDIT BERMASALAH DENGAN PELAKSANAAN LELANG JAMINAN HAK TANGGUNGAN
}

\author{
Lusia Sulastri \\ Advokat \\ lucylaw.cbn74@gmail.com
}

\begin{abstract}
The resolutions of non-performing loans with tendering guarantee Encumbrance often bring up the resistance of the debtor in the form of Civil Lawsuit filed to the District Court which is due to the complexity of the auction and several weaknesses inherent in the Mortgage Law. Issues that will be examined is the debtor regarding the cause of resistance and constructing legal protection for the debtor, which will then be analyzed by juridical reasons debtor resistance and constructing legal protection for debtors. With the use of methods of doctrinal research is normative juridical will be reviewed by the study of civil cases in the District Court Majalengka and Cirebon.

Research into the problem of resistance debtor caused the weaknesses that exist in the Law on Mortgage in particular Article 6 and Article 20 were used as opportunities in filing opposition by the debtor. Clauses are not clear and are not firmly set on the definition of injury Promise of a debtor, limit the authority becomes the object of Encumbrance, and the main thing is the complexity of the auction mainly related to the determination of the value of the object of encumbrance limit unilaterally by the creditor is considered unnatura.

Resistance debtor raise s the conception of the construction of legal protection to the debtor will be maintained, as well as the Law on Consumer Protection which regulates legal protection for debtors and also provides protection against collateral in the debtor from the arbitrariness of the determination of the limit value by "Tendering Crime "in the tendering process the security object security rights.

Weakness contained in UUHT and determination of limit values of objects in the tendering process encumbrance become the subject matter of this study. For it is very important that creditors be cautious in making loans to its customers, in the handling of non-performing loans, especially the tendering security rights regarding the value of the object of the tender limit creditors should remain guided by the principles of good faith and respect for the property of a person.
\end{abstract}

\section{Keyword : Non Performing Loans, Tendering Process of Mortgage (Insurance Right/ Hak Tanggungan) Collateral, Debtor Legal Protection}

\section{Abstrak}

Resolusi kredit bermasalah dengan jaminan tender Pembatasan sering menimbulkan resistensi debitur berupa Tuntutan Sipil yang diajukan ke Pengadilan Negeri yang disebabkan oleh kompleksitas pelelangan dan beberapa kelemahan yang melekat dalam Hukum Hipotek. Permasalahan yang akan diteliti adalah debitur mengenai penyebab resistensi dan pembangunan perlindungan hukum bagi debitur, yang kemudian akan dianalisis secara yuridis alasan penolakan debitur dan pembangunan perlindungan hukum bagi debitur. Dengan menggunakan metode penelitian doktrinal adalah yuridis normatif akan ditinjau kembali oleh studi kasus perdata di Pengadilan Negeri Majalengka dan Cirebon. 
Meneliti masalah penolakan debitur menyebabkan kelemahan yang ada dalam UU tentang Hipotek khususnya Pasal 6 dan Pasal 20 digunakan sebagai peluang dalam mengajukan penolakan oleh debitur. Klausul tidak jelas dan tidak tegas ditetapkan pada definisi cedera Janji seorang debitur, membatasi kewenangan menjadi objek pembatas, dan yang terpenting adalah kompleksitas pelelangan yang terutama berkaitan dengan penentuan nilai objek dari Batas batas secara sepihak oleh kreditor dianggap tidak wajar.

Resistance debitur menimbulkan konsepsi pembangunan perlindungan hukum kepada debitur yang akan dipertahankan, serta UU Perlindungan Konsumen yang mengatur perlindungan hukum bagi debitur dan juga memberikan perlindungan terhadap jaminan di debitur dari kesewenangwenangan penentuan batas Nilai oleh "Tendering Crime" dalam proses tender hak keamanan objek keamanan.

Kelemahan yang terkandung dalam UUHT dan penentuan nilai batas benda dalam proses tender pembebanan menjadi pokok pembahasan penelitian ini. Karena sangat penting bagi kreditor untuk berhati-hati dalam memberikan pinjaman kepada nasabahnya, dalam penanganan kredit bermasalah, terutama hak keamanan tender mengenai nilai objek dari batas tender kreditor harus tetap dipandu oleh prinsip-prinsip itikad baik. Dan menghormati properti seseorang.

Kata Kunci: Kredit Bermasalah, Proses Tender Jaminan Hipotek (Hak Asuransi / Hak Tanggungan), Perlindungan Hukum Debitur

\section{A. Pendahuluan}

Dinamika bisnis dengan pasang surutnya mempunyai akibat terhadap keberlangsungan hubungan suatu kontrak, seperti dalam hal ini penulis menyoroti kontrak / perjanjian perbankan ; apa yang diproyeksikan lancar, untung, memuaskan, namun apa daya prospek bisnis yang diharapkan cerah kadang kala dapat berubah merugi dan memutus hubungan para pihak dalam suatu kontrak. Para pihak yang yang berkontrak senantiasa berharap kontraknya berakhir dengan 'happy ending' namun ternyata ada kemungkinan kontrak menemui hambatan bahkan berujung kepada kegagalan kontrak yang menimbulkan sengketa dan konflik pada para pihaknya.

Dalam suatu pemberian kredit, bank atau pihak pemberi selalu berharap agar debitur dapat memenuhi kewajibannya untuk melunasi tepat pada waktunya terhadap kredit yang sudah diterimanya. Dalam praktek, tidak semua kredit yang sudah dikeluarkan oleh bank dapat berjalan dan berakhir dengan lancar. Tidak sedikit pula terjadinya kredit bermasalah disebabkan oleh debitur tidak dapat melunasi kreditnya tepat pada waktunya sebagaimana yang telah disepakati dalam Perjanjian Kredit antara pihak debitur dan perusahaan perbankan. Hal-hal yang menyebabkan terjadinya kredit bermasalah misalnya karena debitur tidak mampu atau karena mengalami kemerosotan usaha dan gagalnya usaha yang mengakibatkan berkurangnya pendapatan usaha debitur atau memang debitur segaja tidak mau membayar karena karakter debitur tidak baik.

Berdasar keadaan debitur yang demikian, maka pihak kreditur berupaya mengambil pelunasan piutang dengan penjualan asset jaminan debitur sehingga lahirlah Undang-Undang Hak Tanggungan (UUHT) yang dirancang memberikan kepastian hukum sebagai hak jaminan yang kuat, dengan ciri khas eksekusi "mudah dan pasti" namun ternyata dalam pratiknya tidak demikian. Proses penyelesaian kredit bermasalah dengan pelaksanaan lelang jaminan hak tanggungan sering memunculkan perlawanan dari pihak debitur (nasabah) berupa gugatan perdata yang dilayangkan ke Pengadilan Negeri.

Penelitian terhadap perkara gugatan perdata No. 09/Pdt.G/2013/PN.Mjl, No. 81/Pdt.G/2013/ PN.Cbn, dan No. 10/Pdt.G/2014/PN.Mjl bertujuan menganalisis kelemahan-kelemahan yang ada pada Undang-Undang Hak Tanggungan khususnya Pasal 6 dan Pasal 20 yang dijadikan peluang dalam mengajukan perlawanan oleh pihak debitur. Pasal-pasal tersebut nampak tidak jelas dan tidak tegas mengatur tentang definisi Cedera Janji (wan prestasi) seorang 
debitur, batasan kewenangan menjual objek Hak Tanggungan yang menimbulkan kerancuan, serta kompleksitas pelaksanaan lelang terutama terkait dengan penetapan nilai limit obyek lelang secara sepihak oleh kreditur yang dinilai tidak wajar.

Berdasar perkara-perkara perlawanan debitur tersebut memunculkan konsepsi konstruksi perlindungan hukum bagi debitur agar proporsionalitas kepentingan baik pihak debitur maupun kreditur bisa terjaga, sebagimana juga Undang-Undang Perlindungan Konsumen yang mengatur perlindungan hukum bagi debitur dan juga memberikan persfektif perlindungan terhadap aset jaminan debitur dari kesewenang-wenangan penentuan nilai limit oleh "Mafia Lelang" dalam proses lelang objek jaminan hak tanggungan tersebut.

Selain itu terhadap pihak kreditur (bank) sendiri ketidaktegasan Undang-Undang Hak Tanggungan telah berdampak buruk pada aspek efisiensi pelaku ekonomi karena proses dan prosedur penyelesaian kredit bermasalah dengan pelaksanaan lelang memakan waktu lama dan berbelit serta biaya yang sangat tinggi.

Fenomena perlawanan debitur ini mengindikasikan bahwa penegakan hukum eksekusi hak tanggungan adalah salah satu sisi gelap dari penegakan hukum di Indonesia. Hal inilah yang menjadi dasar pemikiran penulis untuk melakukan penelitian lebih lanjut tentang keberlakuan Undang Undang Hak Tanggungan dengan stressing penyelesaian kredit bermasalah dengan pelaksanaan lelang hak tanggungan yang direlevansikan dengan Perkara Perlawanan Debitur terhadap pelaksanaan lelang hak tanggungan di Pengadilan Negeri Majalengka dan Pengadilan Negeri Cirebon.

\section{B. Perumusan Masalah}

1. Apa yang menjadi penyebab penyelesaian kredit bermasalah dengan pelaksanaan lelang jaminan Hak Tanggungan mendapat perlawanan debitur?

2. Bagaimana konstruksi perlindungan hukum debitur dalam penyelesaian kredit bermasalah dengan pelaksanaan lelang jaminan Hak Tanggungan?

\section{Pembahasan}

1. Alasan Yuridis Perlawanan Debitur terhadap Penyelesaian Kredit Bermasalah Dengan Pelaksanaan Lelang Jaminan Hak Tanggungan

Peluang Debitur melakukan perlawanan terhadap proses penyelesaian kredit bermasalah dengan lelang jaminana Hak Tanggungan sangat besar karena Undang-Undang Hak Tanggungan (UUHT) tidak mengatur mengenai definisi cidera janji, maka untuk menentukan apakah debitur cedera janji dalam penentuan pemenuhan Pasal 6 UUHT dirujuk pada Pasal 1243 jo. Pasal 1763 KUH Perdata : Dalam ketentuan Pasal 1243 KUH Perdata, yang dimaksud dengan cedera janji atau wanprestasi :

1. Lalai memenuhi perjanjian, atau

2. Tidak menyerahkan atau membayar dalam jangka waktu yang ditentukan, atau

3. Tidak berbuat sesuai yang dijanjikan dalam tenggang waktu yang ditentukan.

Lebih spesifik Pasal 1763 KUH Perdata mengatakan, tidak mengembalikan pinjaman sesuai dengan jumlah pinjaman dalam jangka waktu yang ditentukan. Sebagai perbandingan, di beberapa negara diatur lebih rinci kapan debitur disebut cedera janji atau default :

1. Melanggar salah satu ketentuan perjanjian yang berkenaan dengan :

a. Pokok pinjaman, dan/atau

b. Bunga (interest), yakni tidak membayar bunga paling tidak dua (2) bulan.

2. Pelanggaran itu telah diberitahukan kepada debitur, namun meskipun sudah lewat tiga (3) bulan, tidak diindahkan.

Dalam keadaan yang seperti inilah debitur dikategori had been in breach of some covenant in the mortgage deed.

Selain itu Pasal 1267 KUH Perdata memberi hak opsi kepada kreditur untuk mengambil tindakan apabila debitur wanprestasi, tanpa mempersoalkan apakah perjanjian telah jatuh tempo atau tidak berupa ketentuan :

a. Meminta atau menuntut kepada pengadilan untuk memaksa debitur memenuhi perjanjian, jika hal itu masih bisa dilakukan oleh debitur

b. Menuntut pembatalan perjanjian disertai 
dengan penggantian biaya kerugian dan bunga.

Sehubungan dengan penjelasan terkait jantuh tempo kredit, tidak dapat disetujui atau tidak tepat pendapat Mahkamah Agung dalam Putusan No. 2/72 K/Pdt/1992 tanggal 29 Mei 1998 yang menyatakan :

Karena Pengadilan Tinggi Aceh / judex facti salah menerapkan hukum, menilai jatuh tempo pelunasan pinjaman dan "Pernyataan Bersama" yang diharuskan oleh ketentuan Pasal 10 UU No. 49 Perpu Tahun 1960 dengan hanya mendasarkan pada lamanya pinjaman tidak dibayar oleh Pemohon Kasasi/Terbanding/ Pelawan tanpa mempertimbangkan tenggang waktu, yaitu tempo pelunasan jaminan.

Pertimbangan diatas kurang jelas rumusannya namun dapat dianggap merupakan pembenaran atas alasan kasasi yang diajukan Pemohon Kasasi, bahwa dalam kasus perkara ini belum terjadi kredit macet karena batas jangka waktu pelunasan kredit belum jatuh tempo, sebab jatuh tempo yang diperjanjikan adalah bulan Desember 1992. Dengan demikian, Bank melalui PUPN belum dapat melakukan eksekusi penjualan lelang terhadap harta kekayaan debitur.

Dapat dilihat, dalam kasus eksekusi ini, Mahkamah Agung berpendapat eksekusi terhadap HT atau harta kekayaan debitur melalui PUPN tidak dapat dilaksanakan atas alasan wanprestasi, selama batas jangka waktu pelunasan kredit yang diperjanjikan belum jatuh tempo. Pendapat Mahkamah Agung yang mengambil alih pertimbangan Pengadilan Negeri dalam kasus ini sangat berbahaya dalam lalu lintas perkreditan. Misalkan, jatuh tempo pelunasan kredit yang diperjanjikan 10 tahun, tetapi baru tahun pertama debitur sudah ingkar membayar angsuran pokok dan bunga. Dalam kasus ini jika pendapat Mahkamah Agung tersebut diikuti penerapannya, berarti kreditor atau bank baru dapat menuntut pembayaran setelah dilewati jangka waktu 10 tahun.

Pendapat dan penerapan yang demikian, satu segi memberi keleluasaan kepada debitur melakukan kesewenangan. Sebaliknya pendapat itu menempatkan kreditor sebagai pihak yang tidak berdaya menghadapi kesewenangan yang di maksud.
Sehubungan dengan itu, dalam kasus tersebut lebih tepat dan lebih berdasar pendapat Pengadilan Tinggi dalam tingkat banding. Menurut Pengadilan Tinggi (disadur sebagai berikut) :

- Telah terbukti kredit telah macet berdasarkan fakta bahwa Pelawan/Debitur sudah bertahuntahun tidak membayar angsuran pinjaman pokok dan bunga, dan hal yang demikian menurut Pasal 3 ayat (3) Peraturan Menteri Keuangan No. 2/PMK 01/1997, termasuk pinjaman kredit investasi yang macet ;

- Selain itu, Pasal 6 ayat (3) menegaskan, Bank/Kreditor dapat menyatakan kredit jatuh tempo seketika apabila debitur wanprestasi dan kreditnya digolongkan macet, dengan cara mengesampingkan jatuh tempo yang ditentukan dalam perjanjian ;

- Mengenai Surat Pernayataan Bersama antara Pelawan/Debitur dengan PUPN, berdasarkan Pasal 10 Perpu No. 49 Tahun 1960, tidak mungkin diadakan atas alasan :

a. Pelawan/Debitur telah 4 kali dipanggil PUPN, tetapi tetap tiak hadir ;

b. Dalam hal yang demikian, berdasarkan Pasal 11 Perpu No. 49 Tahun 1960, PUPN dapat segera menerbitkan Surat Paksa unutuk menagih piutang negara dari debitur :

c. Dengan demikian, sita eksekusi dan penjualan lelang yang telah dilakukan PUPN dan Kantor Lelang dalam kasus perkara ini adalah sah menurut hukum.

Pertimbangan dan pendapat Pengadilan Tinggi di atas, selain rasional dan objektif, juga dilandasi peraturan perundang-undangan yang kuat serta dibarengi dengan pemahaman yang tepat mengenai pengertian wanprestasi yang digariskan Pasal 1243 dan Pasal 1763 KUH Perdata. Oleh karena itu, yang layak diikuti adalah pendapat Pengadilan Tinggi, bukan pendapat Mahkamah Agung.

Konsep Pembentuk Undang-Undang Hak Tanggungan pada awalnya adalah memberikan kemudahan kepada kreditur, agar kreditur dapat mendapatkan kembali uangnya dengan jalan yang lebih mudah dan murah, maka Pasal 6 UUHT yang secara ex lege juga dapat memperkuat kedudukan kreditur manakala debitur cedera janji, yakni dengan memberikan ketentuan yang 
dapat digunakan berupa hak untuk menjual atas kekuasaan sendiri atas objek jaminan guna mengambil pelunasan pinjaman. Untuk lebih jelasnya dalam Pasal 6 UUHT, menyebutkan :

"Apabila debitur cidera janji, Pemegang Hak Tanggungan mempunyai hak untuk menjual objek Hak Tanggungan atas kekuasaan sendiri melalui pelelangan umum serta mengambil pelunasan piutang dari hasil penjualan tersebut". ${ }^{1}$

Pemahaman pasal tersebut dapat dikatakan bahwa sama sekali hak menjual atas kekuasaan sendiri tidak lagi memperjanjikan melalui kuasan atau pelaksanaannya sudah tidak didasarkan atas kuasa lagi, sebab pemberian parate eksekusi oleh undang-undang (ex lege), dengan tujuan demi dan untuk memperkuat posisi dari kreditur pemegang Hak Tanggungan dan pihak-pihak yang mendapatkan hak dari padanya.

Pasal 6 UUHT memberikan pemahaman secara tegas bahwa kewenangan menjual atas kekuasaan sendiri diberikan kepada pemegang pertama Hak Tanggungan, sekalipun tidak terdapat janji yang tertuang dalam Akta Pembebanan Hak Tanggungan, yang dikenal dengan sebutan beding van eigenmatig verkoop. Hal tersebut menunjukkan penyatuan suatu kewenangan yang pada awalnya lahir dari sebuah kesepakatan (janji) menjadi sebuah norma yang mengikat, karena diberikan oleh undang-undang (ex legie), itu merupakan suatu peekembangan yang mengarah pada suatu kemajuan dibandingkan ketentuan dalam Pasal 1178 ayat (2) B.W. saat berlakunya hipotik.

Namun apabila membaca Penjelasan Pasal 6 UUHT kemudian dihubungkan dengan Pasal 6 UUHT akan menimbulkan kebingungan, sebab dalam Penjelasan pasal tersebut menentukan bahwa :

"Hak tersebut yaitu hak untuk menjual objek Hak Tanggungan atas kekuasaan sendiri merupakan salah satu perwujudan dari kedudukan diutamakan yang dipunyai oleh Pemegang Hak Tanggungan atau Pemegang Hak Tanggungan Pertama dalam hal terdapat lebih dari satu (1) Pemegang Hak

1 Poesoko Herowati. 2007. Parate Executie Obyek Hak Tanggungan (Inkonsistensi, Konflik Norma dan Kesesatan Penalaran dalam UUHT). Yogyakarta ; Penerbit LaksBang PRESSindo. Hal. 249
Tanggungan. Hak tersebut didasarkan Pada Janji apabila debitur cedera janji, pemegang Hak Tanggungan berhak untuk menjual objek Hak Tanggungan melalui pelelangan umum tanpa memerlukan persetujuan lagi dari pemberi Hak Tanggungan dan selanjutnya mengambil pelunasan piutangnya dari hasil penjualan itu lebih dahulu dari kreditor-kreditor yang lain ...".

Menurut Penjelasan Pasal 6 UUHT setidaktidaknya memberika 2 (dua) pemahaman, pertama, hak kreditor untuk menjual objek Hak Tanggungan atas kekuasaan sendiri didasarkan pada janji apabila debitur cedera janji, dan kedua, hak untuk menjual objek Hak Tanggungan atas kekuasaan sendiri merupakan salah satu perwujudan dari kedudukan diutamakan yang dipunyai oleh Pemegang Hak Tanggungan.

Terhadap hak untuk menjual atas kekuasaan sendiri, menurut Penjelasan Pasal 6 UUHT didasarkan pada janji. Hal tersebut sangatlah berbeda dengan Pasal 6 UUHT yang memberikan hak menurut undang-undang (ex lege). Adanya perbedaan makna terhadap lahirnya hak kreditur untuk menjual objek Hak Tanggungan atas kekuasaan sendiri menunjukkan pembentuk UUHT yang mempunyai sikap yang tidak konsisten, yang menyebabkan kebingungan dan kekecewaan bagi kreditur pada khususnya, sehinggan Penjelasan Pasal 6 UUHT tersebut justru kembali mementahkan harapan perbankan. Sebenarnya hukum hanya memberikan harapan perbankan, tetapi justru menunjukkan riskan bila dalam satu undang-undang (UUHT) mengatur satu objek yang sama yaitu parate eksekusi, tetapi memberikan makna yang berbeda satu sama lain. Perbedaan makna tersebut tercermin dalam Pasal 6 UUHT, bahwa hak menjual atas kekuasaan sendiri diberikan oleh undangundang (ex lege), tetapi penafsiran otentik dari pembentuk UUHT sebagaimana dalam Penjelasan Pasal 6, ternyata hak menjual atas kekuasaan sendiri, tidak dimaksudkan secara ex lege tetapi atas dasar diperjanjikan terlebih dahulu. Pengaturan ini menjadi berlebihan dan akan menimbulkan silang pendapat yang tiada henti-hentinya, bahwa dapat dikatakan terjadi inkonsisten dalam pengaturannya.

2 Ibid. Hal. 250 
Pada dasarnya susunan tata aturan yang penuh konsistensi, tidak lepas dari hubungannya dengan sistematika peraturan-peraturan hukum yang lain, sebab hukum merupakan suatu sistem artinya sarana yang merupakan suatu kesatuan yang utuh yang terdiri dari bagian-bagian atau unsur-unsur yang saling terkait satu sama lain, atau dengan perkataan lain sistem hukum adalah suatu kesatuan yang terdiri dari unsur-unsur yang mempunyai interaksi satu sama lain dan bekerja sama untuk mencapai tujuan kesatuan tersebut. Kesatuan tersebut diterapkan terhadap kompleks unsur-unsur yuridis, seperti peraturan hukum, asas hukum dan pengertian hukum. Adanya pengaturan yang inkonsisten terhadap hak kreditor yang diatur dalam Pasal 6 UUHT dengan Penjelasan dalam Pasal 6, maka demi dan untuk perlindungan hukum dan kepastian hukum bagi kreditur tersebut, perlu adanya sandaran berpijak untuk mencari solusi atas kerancuan pengaturan tersebut.

Berpijak pada Keputusan Presiden RI No. 44 Tahun 1999 tentang Penyusunan Peraturan Perundang-undangan dan Bentuk Rancangan Undang-Undang, Rancangan Peraturan Pemerintah dan Rancangan Keputusan Presiden, tanggal 19 Mei 1999, Lembaran Negara Republik Indonesia tahun 1999 Nomor 70, pada II, tentang Hal-Hal Khusus, II A, Penjelasan dinyatakan :3

"Pada dasarnya rumusan penjelasan peraturan perundang-undangan tidak dapat dijadikan sebagai sandaran bagi materi pokok yang diatur dalam batang tubuh. Karena itu, penyusunan rumusan norma dalam batang tubuh harus jelas dan tidak menimbulkan keragu-raguan".

Apabila peraturan tersebut diatas dikaitkan dengan Penjelasan Pasal 6 UUHT, maka Penjelasan dari Pasal 6 UUHT tidak dapat dijadikan sandaran bagi materi pokok yang diatur dalam batang tubuh yang adalah Pasal 6 UUHT. Penjelasan suatu norma tidak boleh bertentangan dengan isi (substansi) normanya, dan Penjelasan dari norma tersebut tidak mengikat, karena Penjelasan suatu norma bukanlah suatu norma. Sehubungan Penjelasan Pasal 6 UUHT bukan norma manakala terjadi sengketa, maka kedudukan Penjelasan Pasal 6 UUHT tersebut tidak mempunyai kekuatan berlaku mengikat.

3 Ibid. Hal. 253
Sehingga dengan mendasarkan alasan tersebut, jelas hak kreditur pemegang Hak Tanggungan pertama untuk menjual objek Hak Tanggungan adalah atas dasar undang-undang, bukan atas dasar diperjanjikan.

Lebih lanjut dalam Penejelasan Pasal 6 UUHT, Pembentuk UUHT juga telah mencampuradukan parate executie dengan kedudukan kreditur preferen. Untuk mengkaji hal tersebut, dengan bertitik tolak dari jenis hak yang terkandung dalam UU No. 4/1996. Sebenarnya Hak Tanggungan merupakan suatu jenis hak yang eksistensinya lahir lewat perjanjian yang diadakan oleh para pihak. Perjanjian jaminan yang melahirkan Hak Tanggungan ini, dibuat oleh para pihak dengan tujuan untuk melengkapi perjanjian pokok yang umumnya berupa perjanjian utang piutang atau perjanjian kredit. Sehubungan berdasar kesepakatan jaminan yang diberikan oleh debitur adalah tanah (benda tidak bergerak), berarti para pihak akan membuat perjanjian jaminan Hak Tanggungan. Perjanjian ini terkualifikasi sebagai perjanjian kebendaan, sehingga Hak Tanggungan yang lahir tergolong sebagai kebendaaan (zakelijk). Seperti diketahui bahwa hak kebendaan memiliki ciri-ciri yang sangat unggul seperti ada preferensi, droit de suit, priorotas, dan bersifat mutlak. Akibat lanjutnya, kreditor atau bank yang memiliki Hak Tanggungan yang tergolong sebagai kreditor preferen, bukan lagi sebagai kreditor konkruen.

Walaupun undang-undang tidak memberikan penjelasan resmi mengenai apa yang dimaksud dengan "kedudukan yang diutamakan", tetapi berpijak dari Pasal 1 ayat (1) UUHT, tetapi dengan mengingat akan kedudukan pemegang hipotik dalam B.W. sebagai kreditor preferen, kiranya boleh diduga, bahwa yang dimaksud dengan "kedudukan yang diutamakan" sama dengan "kedudukan sebagai kreditur preferen". Untuk hal tersebut perlu mengetahui tentang "Kedudukan sebagai kreditur preferen”, berarti, kreditur pemegang hak jaminan tersebut didahulukan di dalam mengambil pelunasan atas hasil eksekusi benda pemberi jaminan tertentu yang dalam hubungannya dengan Hak Tanggungan secara khusus diperikatkan untuk menjamin tagihan kreditor. Dengan demikian, kedudukan sebagi kreditur preferen baru mempunyai peranannya 
dalam suatu eksekusi terhadap objek jaminan manakala debitur wanprestasi, maka dalam mengambil pelunasan piutangnya, kreditor preferen diberi hak terlebih dahulu daripada kreditur lainnya.

Kalau benar maksud pembuat undangundang seperti tersebut diatas, maka lebih lanjut ketentuan Pasal 1 ayat (1) UUHT yang dihubungkan dengan Pasal 20 ayat (1b) UUHT, yang terletak pada Bab V tentang Eksekusi Hak Tanggungan, yang mengatur :4

“... untuk pelunasan piutang pemegang Hak Tanggungan dengan hak mendahului daripada kreditur-kreditur lainnya".

Kata "hak mendahului" kalau dihubungkan dengan peristiwa "eksekusi" tentunya berarti "didahulukan" dalam mengambil pelunasan atas hasil eksekusi dari benda atau benda-benda yang dijaminkan. Sehingga, kedudukan kreditor pemegang Hak Tanggungan disebut sebagai "diutamakan", sedang pelaksanaan haknya disebut "didahulukan". Maksudnya didahulukan eksekusinya dari kreditur yang lain, sekalipun tidak diberikan penjelasan lebih lanjut oleh undang-undang, namun kiranya sekali lagi berdasarkan pengalaman mengenai hipotik boleh menduga, bahwa yang dimaksud adalah didahulukan terhadap kreditor konkruen, sebagai dasar pemikirannya adalah Pasal 1132 jo Pasal 1138 B.W.

Sebagai konsekuensi adanya kedudukan pemegang Hak Tanggungan yang diutamakan atau mendahulu, maka objek Hak Tanggungan dapat dibebani lebih dari satu Hak Tanggungan, sehingga terdapat pemegang Hak Tanggungan peringkat pertama, peringkat kedua dan seterusnya, sehingga dengan sendirinya pemegang Hak Tanggungan yang lebih tua akan mempunyai kedudukan yang lebih tinggi dibandingkan dengan pemegang Hak Tanggungan berikutnya. Penentuan peringkat pemegang Hak Tanggungan telah diatur dalam Pasal 5 UUHT. Sehingga hak tagih kreditor yang memiliki posisi sebagai kreditor preferen, posisi kreditor tersebut menjadi sangat kuat. Menurut Isnaeni, pola ini dapat diandalkan untuk menunjang kegiatan bisnis para pelaku ekonomi yang selalu menginginkan efisiensi. Kreditor dengan kedudukan yang diutamakan $4 \quad$ Ibid. Hal 255 tersebut, sudah barang tentu tidak mengurangi preferensi piutang-piutang negara menurut ketentuan-ketentuan hukum yang berlaku.

Tetapi ternyata apabila membaca penjelasan dari Pasal 6 UUHT yang menyebutkan $:^{5}$

"Hak untuk menjual objek Hak Tanggungan atas kekuasaan sendiri merupakan salah satu perwujudan dari kedudukan diutamakan yang dipunyai oleh pemegang Hak Tanggungan atau pemegang Hak Tanggungan pertama dalam hal terdapat lebih dari satu pemegang Hak Tanggungan ..."

Pemahaman terhadap penjelasan dari Pasal 6 UUHT, ternyata pembentuk undang-undang mencampuradukkan antara hak untuk menjual objek Hak Tanggungan atas kekuasaan sendiri (parate executie) dengan perwujudan kedudukan diutamakan yang dipunyai oleh pemegang Hak Tanggungan (kreditor preferen). Menurut J. Satrio, kewenangan parate eksekusi bukan merupakan perwujudan dari kedudukan kreditor sebagai kreditor yang diutamakan/preferen, yang benar adalah merupakan perwujudan dari salah satu segi dari kedudukan kreditor yang memperjanjikan hak jaminan khusus, atau yang oleh undangundang diberikan kewenangan khusus, yaitu memberikan kemudahan kepada kreditor dalam mengambil pelunasan. Penulis sependapat dengan J. Satrio, dengan alasan kalau hak untuk menjual objek Hak Tanggungan atas kekuasaan sendiri adalah bukan perwujudan kedudukan diutamakan, tetapi sebagai perwujuan prinsip mempercepat pelunasan piutang kreditor, karena parate executie merupakan prinsip eksekusi yang menyimpang dari eksekusi yang diatur dalam Hukum Acara Perdata. Sedangkan kedudukan kreditor preferen menunjukkan bahwa pemenuhan prestasinya lebih didahulukan dari piutang yang lain yang timbul dari perjanjian jaminan khusus.

Adanya kerancuan dalam Penjelasan Pasal 6 UUHT sedikit banyak membingungkan para pemegang jaminan, khususnya bagi kreditor pemegang Hak Tanggungan pertama, karena meskipun pada dasarnya lahirnya parate executie dapat diperjanjikan dan akan mengikat pada para pihak, namun sebagai norma harus jelas dan tegas agar tidak menimbulkan pemahaman ganda yang berakibat memberikan arti yang

5 Ibid. Hal. 256 
kabur, sehingga menimbulkan peluang penafsiran berbeda-beda, yang mengakibatkan terlupakan tujuan semula dibentuknya Pasal 6 UUHT.

Karakter parate eksekusi dan menjual atas kekuasaan sendiri atau eigenmachtige verkoop (the right to sale), namun penerapannya mengacu pada kejelasan berikut.

Pelaksanaan parate eksekusi tunduk kepada Pasal 224 HIR, Pasal 256 RBG apabila tidak diperjanjikan kuasa menjual sendiri :

- Penjualan lelang (eexecutoriale verkoop) harus diminta kepada Ketua PN ;

- Permintaan berdasarkan alasan cidera janji atau wanprestasi ;

Apa yang dimaksud cidera janji, tidak diatur dalam Pasal 6 UUHT

a. Dengan demikian, untuk menentukan adanya cidera janji merujuk kepada ketentuan Pasal 1243 KUH Perdata ;

b. Atau sesuai dengan kesepakatan yang diatur dalam perjanjian ;

c. Atau jika merujuk secara analog dengan ketentuan Pasal 1178 KUH Perdata, yang dikategori cidera janji apabila debitur :

- Tidak melunasi utang pokok, atau

- Tidak membayar bunga yang terutang sebagaimana mestinya.

Ketentuan pasal ini mengandung kerancuan jika dihubungkan dengan penjelasan Pasal 6 tersebut. Satu segi, Pasal 6 sendiri memberi kuasa menjual sendiri kepada pemegang HT apabila debitur cedera janji. Akan tetapi, pada penjelasan pasal itu sendiri, ditegaskan kepada pemegang HT untuk menjual sendiri (rechts van eigenmachtige verkoop) baru melekat apabila hal itu diperjanjikan. Jadi, satu segi berdasarkan pasal ini, tersirat rumusan bahwa kuasa menjual sendiri seolah-olah bersifat ipso jure (by law) diberikan undang-undang kepada pemegang $\mathrm{HT}$, namun berdasarkan penjelasan pasal itu, tidak bersifat ipso jure, tetapi harus berdasarkan kesepakatan.

Menurut penjelasan ini, hak untuk menjual objek Hak Tanggungan atas kekuasaan sendiri, merupakan salah satu perwujudan dari kedudukan diutamakan atau hak preferen yang dimiliki pemegang Hak Tanggungan atau pemegang Hak Tanggungan pertama, apabila pemegang Hak Tanggungan lebih dari satu orang.
1. Hak menjual atas kekuasaan sendiri baru melekat apabila diperjanjikan secara tegas dalam Akta Pembebanan Hak Tanggungan

- Pemberian hak itu menurut Penjelasan Pasal 6, harus didasarkan pada "janji" atau "klausul" ysng diberikan debitur atau Pemberi Hak Tanggungan kepada Pemegang Hak Tanggungan (kreditur) ;

- Janji itu berisi penegasan : apabila debitur atau pemberi Hak Tanggungan cedera janji, pemegang Hak Tanggungan berhak menjual objek Hak Tanggungan melalui pelelangan umum tanpa memerlukan persetujuan lagi dari pemberi Hak Tanggungan.

2. Dari hasil penjualan, kreditor mengambil pelunasan lebih dahulu:

- Kreditor berhak mengambil pelunasan atas seluruh utang dari hasil penjualan lebih dahulu, dengan jalan mengesampingkan kreditor lain

- Jika masih ada sisa, menjadi hak pemberi Hak Tanggungan, oleh karena itu harus diserahkan kepadanya.

Konsep dan sistem menjual atas kekuasaan sendiri yang diatur dalam Pasal 6 UUHT, sama dengan yang digariskan Pasal 1178 KUH Perdata, yakni harus ditegaskan sebagai klausul dalam Akta Pembebanan Hak Tanggungan (APHT).

Undang-Undang Hak Tanggungan sampai saat ini belum mengatur mengenai Peraturan Pelaksanaannya. Sehingga berdasarkan penjelasan sebelumnya maka dapat dipahami bahwa lelang Hak Tanggungan harus melalui permohonan fiat (penetapan) kepada Ketua Pengadilan Negeri yang berwenang. Hal ini sesuai dengan Pasal 224 HIR yang mengatur mengenai lembaga parate eksekusi.

Tanpa melalui lembaga parate eksekusi sesuai Pasal 224 HIR maka dapat dikatakan proses lelang eksekusi Hak Tanggungan yang dilakukan pihak perbankan karena nasabah debiturnya macet secara langsung ke lembaga lelang adalah masuk dalam kategori tidak sesuai dengan peraturan perundang-undangan (undue process the law).

Sebagaimana yang banyak terjadi, bila suatu lelang eksekusi Hak Tanggungan yang secara langsung dilakukan melaui Lembaga Lelang akan 
banyak mendapat Perlawanan dari debiturnya. Biasanya melalui suatu perdebatan keadaan jumlah hutang yang pasti. Meskipun melalui upaya Perlawanan ini akhirnya pokok perkara diperiksa oleh Pengadilan namun kiranya telah melanggar hukum perdata yang seharusnya. Disini belum terjadi unifikasi hukum karena sikap Mahkamah Agung juga tidak tegas atau bahkan mendua dalam menentukan hukum acara lelang eksekusi Hak Tanggungan yang seharusnya. Yurisprudensi Mahkamah Agung belum tegas mengaturnya sehingga banyak pihak baik dari perbankan ataupun debitur mencoba-coba melakukan tindakan-tindakan hukum tersebut.

Sebagai penekanan dalam maksud pengertian Undang-Undang, berikut disitir bunyi Putusan Mahkamah Agung Republik Indonesia No. 3210 K/Pdt/1984 tanggal 30 Januari 1986 yang dalam pertimbangan amarnya menyatakan sebagai berikut :

- Pelaksanaan eksekusi prosse akta hipotek yang berkepala Demi Keadilan Berdasarkan Ketuhanan Yang Maha Esa berdasarkan Pasal 224 HIR, mempunyai kekuatan yang sama dengan Putusan Pengadilan yang berkekuatan hukum tetap ;

- Namun pelaksanaannya, harus melalui campur tangan Pengadilan Negeri, karena yang dimaksud jawatan umum pada Pasal 1211 Kitab Undang-Undang Hukum Perdata adalah Pengadilan, bukan Kantor Lelang ;

- Oleh karena itu, penjualan lelang yang dilakukan Kantor Lelang Bandung tanpa atas perintah Ketua Pengadilan Negeri, tetapi langsung atas permintaan Bank (Kreditor) adalah tidak sah.

Meskipun Putusan tersebut diatas muncul sebelum berlakunya Undang-Undang No. 4/1996 tentang Hak Tanggungan namun secara pemahaman hukum telah sesuai dengan Pasal 224 HIR jo. Pasal 1211 Kitab Undang-Undang Hukum Perdata. Dalam hal ini belum terdapat UndangUndang atau peraturan baru yang merubahnya maka seharusnya ketentuan lama tersebut yang dipakai. Oleh karena pelaksanaan lelang eksekusi Hak Tanggungan tanpa melalui campur tangan Ketua Pengadilan adalah tidak memenuhi secara hukum acara (undue process of the law).
Melalui campur tangan Pengadilan maka fiat atau Penetapan lebih mencerminkan keseimbangan kepentingan dan memenuhi asas keadilan dalam hal Pengadilan telah memeriksa kecukupan alasan dikeluarkannya Penetapan tersebut. Disamping itu pihak debitur akan mendapatkan Hak Teguran (aanmaning) dan langsung dapat menjelaskan duduk perkaranya kepada Pengadilan yang berwenang. Masingmasing pihak mendapat hak dan kewajiban secara seimbang untuk mempertahankan kepentingannya didepan sebelumnya, yang dipenuhi oleh lembaga lelang karena tidak memiliki ruang pembuktian lagi.

Meskipun pada asasnya lembaga parate eksekusi ditujukan agar eksekusi dapat dilakukan secara serta merta, namun adanya syarat dan ketentuan "apabila debitur cidera janji" dalam Pasal 6 Undang-Undang Hak Tanggungan membuat ekskekusi yang dimaksud adalah kondisional atau bersyarat tertentu. Maraknya gugatan akibat asset jaminan dilelang oleh perbankan disamping efek psikologis tereksekusi, juga sangat dipengaruhi karena begitu longgarnya batasan berlakunya ketentuan undang-undang tersebut.

\section{Perlindungan Hukum Debitur Dalam Persfektif Undang-Undang Nomor 8 Tahun 1999 tentang Perlindungan Konsumen (UUPK) dan Perlindungan Penentuan Nilai Limit Lelang Jaminan Hak Tanggungan}

Konsumen merupakan salah satu pelaku kegiatan perekonomian dalam suatu Negara. Konsumen merupakan individu/sekelompok orang yang mengkonsumsi suatu barang atau jasa yang disediakan oleh produsen. Brikut merupakan pengertian konsumen dari para ahli : 6

a. Philip Kotler "konsumen adalah semua individu dan rumah tangga yang membeli maupun memperoleh barang atau jasa untuk dikonsumsi pribadi".

b. Hornby "konsumen adalah setiap orang pemakai barang dan/ atau jasa yang tersedia dalam masyarakat, baik bagi kepentingan diri sendiri, keluarga, orang lain, maupun makhluk

6 dhika augustyas "Perlindungan Hukum Bagi Konsumen" diakses dalam https://dhiasitsme.wordpress.com/2012/04/18/perlindunganhukum-bagi-konsumen/pada tanggal 10 Mei 2015 pukul 14.34 WIB 
hidup lain dan tidak untuk diperdagangkan".

Konsumen sebagai pemakai barang atau jasa memerlukan suatu perlindungan hukum yang jelas dalam mendapatkan kepuasan serta kelayakan dalam mengkonsumsi barang atau jasa. Perlindungan Konsumen menurut Undangundang No.8 Tahun 1999, pasal 1 butir 1 adalah "segala upaya yang menjamin adanya kepastian hukum untuk memberi perlindungan kepada konsumen". Dalam hal ini maka dalam segala pemakaian produk atau jasa oleh konsumen, konsumen berhak mendapatkan suatu kepastian hukum.

Perlindungan bagi konsumen banyak macamnya, seperti perlindungan kesehatan dan keselamatan konsumen, hak atas kenyamanan, hak dilayani dengan baik oleh produsen maupun pasar, hak untuk mendapatkan barang atau jasa yang layak dan lain sebagainya. Banyaknya hak dalam perlindungan konsumen disebabkan oleh faktor bahwa konsumen adalah pelaku ekonomi yang penting, karena tanpa adanya konsumen dalam produksi barang atau jasa, maka suatu perekonomian tidak akan berjalan. Bila produk/jasa yang dihasilkan tidak sesuai dengan permintaan dari konsumen, maka kepuasan konsumen akan menjadi minimal sehingga terjadi ketimpangan dalam perekonomian maupun produksi suatu barang atau jasa tersebut.

Dalam pasal 2 Undang-Undang No.8/1999 berisi tentang asas perlindungan konsumen dimana dalam pasal tersebut menyatakan bahwa "Perlindungan konsumen berdasarkan manfaat, keadilan, keseimbangan, keamanan dan keselamatan konsumen, serta kepastian hukum". Oleh karena itu, dalam perlindungan konsumen, seharusnya setiap aspek baik produsen maupun pasar serta peran pemerintah sangat diperlukan dan selalu mengacu kepada asas-asas yaitu :7

a. Asas Manfaat dalam hal ini baik pihak produsen maupun konsumen memiliki kedudukan yang sama sehingga tidak ada kerugian dari masingmasing pihak dan dapat memperoleh haknya sebagai produsen serta konsumen.

b. Asas Keadilan merupakan asas yang paling sering dilanggar oleh suatu pihak, karena seharusnya dalam hal ini pelaku usaha 7 Ibid (produsen) berlaku adil dalam menciptakan suatu barang/jasa baik dalam proses pembuatan serta dalam proses penentuan harga. Dengan rasa keadilan yang tinggi, maka tidak ada pihak yang merasa dirugikan dalam hal tersebut.

c. Asas keseimbangan merupakan asas dimana adanya keseimbangan antara kepentingan konsumen maupun produsen serta pihakpihak lain seperti pemerintah sehingga tercipta perekonomian yang baik dan stabil.

d. Asas keamanan dan keselamatan konsumen merupakan suatu asas dimana setiap barang/ jasa yang dihasilkan sudah memenuhi syarat untuk diproduksi dan disetujui oleh badan hukum yang berwenang sehingga produk yang ditawarkan dan dijual kepada konsumen layak untuk dikonsumsi karena dalam penggunaan barang/jasa oleh konsumen hal itu juga menyangkut atas keselamatan konsumen yang harus ditanggung oleh produsen maupun pemerintah jika terjadi suatu kecelakaan.

e. Asas kepastian hukum adalah asas yang membuat para pelaku usaha maupun konsumen dapat mematuhi peraturan yang berlaku sehingga tidak akan melanggar hukum yang telah diatur. Dengan adanya kepastian hukum maka konsumen juga dapat menggunakan produk/jasa dengan rasa aman dan dapat menjadi suatu jamina apabila terjadi sesuatu yang tidak diinginkan dalam penggunaan produk/jasa tersebut.

Selain harus mengacu pada asas, perlindungan konsumen dilaksanakan untuk berbagai macam tujuan. Tujuan perlindungan konsumen menurut pasal 3 Undang-Undang No. 8/1999 yaitu:

a. meningkatkan kesadaran, kemampuan dan kemandirian konsumen untuk melindungi diri;

b. mengangkat harkat dan martabat konsumen dengan cara menghindarkannya dari akses negatif pemakai barang dan/atau jasa;

c. meningkatkan pemberdayaan konsumen dalam memilih, menentukan, dan menuntut hak-haknya sebagai konsumen;

d. menciptakan sistem perlindungan konsumen yang mengandung unsur kepastian hukum dan keterbukaan informasi serta akses untuk mendapatkan informasi; 
e. menumbuhkan kesadaran pelaku usaha mengenai pentingnya perlindungan konsumen sehingga tumbuh sikap yang jujur dan bertanggung jawab dalam berusaha;

f. meningkatkan kualitas barang dan/atau jasa yang menjamin kelangsungan usaha produksi barang dan/ atau jasa, kesehatan , kenyamanan, keamanan, dan keselamatan konsumen.

Pengaturan melalui UUPK yang sangat terkait dengan perlindungan hukum bagi nasabah selaku konsumen perbankan adalah ketentuan mengenai tata cara pencatuman klausula baku. Klausula baku adalah setiap aturan atau ketentuan dan syarat-syarat yang telah diperisiapkan dan ditetapkan terlebih dahulu secara sepihak oleh pelaku usaha yang dituangkan dalam suatu dokumen dan/atau perjanjian yang mengikat dan wajib dipenuhi oleh konsumen.

Adanya perlindungan hukum bagi nasabah selaku konsumen di bidang perbankan menjadi urgent, karena secara faktual kedudukan antara para pihak seringkali tidak seimbang. Perjanjian kredit/pembiayaan dan perjanjian pembukaan rekening bank yang seharusnya dibuat berdasarkan kesepakatan para pihak, karena alasan efisiensi diubah menjadi perjanjian yang sudah dibuat oleh pihak yang mempunyai posisi tawar (bargaining position) dalam hal ini adalah pihak bank. Nasabah tidak mempunyai pilihan lain, kecuali menerima atau menolak perjanjian yang disodorkan oleh pihak bank (take it or leave it). ${ }^{8}$

Pencantuman klausula-klausula dalam perjanjian kredit/pembiayaan pada bank sepatutnya merupakan upaya kemitraan, karena baik bank selaku kreditur maupun nasabah debitur kedua-duanya saling membutuhkan dalam upaya mengembangkan usahanya masing-masing.

Klausula yang demikian ketatnya didasari oleh sikap bank untuk melaksanakan prinsip kehati-hatian dalam pemberian kredit/pembiayaan. Dalam memberikan perlindungan terhadap nasabah debitur perlu kiranya peraturan tentang perkreditan direalisir sehingga dapat dijadikan panduan dalam pemberian kredit. Di sisi lain pengadilan yang merupakan pihak ketiga dalam mengatasi perselisihan antara bank dengan 8 Ibid nasabah debitur dapat menilai apakah upayaupaya yang dilakukan oleh kedua belah pihak telah sesuai dengan yang disepakati dan tidak melanggar ketentuan perundang-undangan.

Keberatan-keberatan terhadap perjanjian standar antara lain adalah karena : ${ }^{9}$

1. Isi dan syarat-syarat sudah dipersiapkan oleh salah satu pihak,

2. Tidak mengetahui isi dan syarat-syarat perjanjian standar dan kalaupun tahu tidak mengetahui jangkauan akibat hukumnya,

3. Salah satu pihak secara ekonomis lebih kuat,

4. Ada unsur "terpaksa" dalam menandatangani perjanjian. Adapun alasan penciptaan perjanjian standar adalah demi efisiensi.

Adanya kondisi demikian, melatarbelakangi substansi UUPK untuk memberikan pengaturan mengenai ketentuan pencantuman klausula baku, yaitu sebagai berikut: ${ }^{10}$

1. Pelaku usaha dalam menawarkan barang dan/ atau jasa yang ditujukan untuk diperdagangkan dilarang membuat atau mencantumkan klausula baku pada setiap dokumen dan/ atau perjanjian apabila:

a. menyatakan pengalihan tanggungjawab pelaku usaha;

b. menyatakan bahwa pelaku usaha berhak menolak penyerahan kembali barang yang dibeli konsumen;

c. menyatakan bahwa pelaku usaha berhak menolak penyerahan kembali uang yang dibayarkan atas barang dan/atau jasa yang dibeli oleh konsumen;

d. menyatakan pemberian kuasa dari konsumen kepada pelaku usaha baik secara langsung, maupun tidak langsung untuk melakukan segala tindakan sepihak yang berkaitan dengan barang yang dibeli oleh konsumen secara angsuran;

e. mengatur perihal pembuktian atas hilangnya kegunaan barang atau pemanfaatan jasa yang dibeli oleh konsumen;

f. memberi hak kepada pelaku usaha untuk mengurangi manfaat jasa atau mengurangi harta kekayaan konsumen yang menjadi obyek jual beli jasa;

9 Ibid

10 Ibid 
g. menyatakan tunduknya konsumen kepada peraturan yang berupa aturan baru, tambahan, lanjutan dan/atau pengubahan lanjutan yang dibuat sepihak oleh pelaku usaha dalam masa konsumen memanfaatkan jasa yang dibelinya;

h. menyatakan bahwa konsumen memberi kuasa kepada pelaku usaha untuk pembebanan hak tanggungan, hak gadai, atau hak jaminan terhadap barang yang dibeli oleh konsumen secara angsuran.

2. Pelaku usaha dilarang mencantumkan klausula baku yang letak atau bentuknya sulit terlihat atau tidak dapat dibaca secara jelas, atau yang pengungkapannya sulit dimengerti.

3. Setiap klausula baku yang telah ditetapkan oleh pelaku usaha pada dokumen atau perjanjian yang memenuhi ketentuan sebagaimana dimaksud pada ayat 1 dan ayat 2 dinyatakan batal demi hukum.

4. Pelaku usaha wajib menyesuaikan klausula baku yang bertentangan dengan Undangundang ini.

Untuk ketentuan dalam Pasal 18 dimaksud yang sangat terkait erat dan sering terjadi dalam perjanjian kredit/pembiayaan yang diberikan oleh bank adalah ketentuan pada ayat (1) huruf g, yakni bahwa bank menyatakan tunduknya konsumen kepada peraturan yang berupa aturan baru, tambahan, lanjutan dan/atau pengubahan lanjutan yang dibuat sepihak oleh pelaku usaha dalam masa konsumen memanfaatkan jasa yang dibelinya.

Ketentuan mengenai klausula baku sudah diatur dalam UUPK, akan tetapi pada kenyataannya sering kali masih terjadi pelanggaran sehingga akan merugikan kepentingan nasabah. Hal-hal yang harus diperhatikan oleh pihak bank untuk menghilangkan atau paling tidak meminimalisir terjadinya kerugian bagi nasabah karena memang harus dalam bentuk perjanjian standar, antara lain adalah sebagai berikut: ${ }^{11}$

1. Memberikan peringatan secukupnya kepada para nasabahnya akan adanya dan berlakunya klausula-klausula penting dalam perjanjian.

2. Pemberitahuan dilakukan sebelum atau pada saat penandatanganan perjanjian kredit/ pembiayaan.

11 Ibid
3. Dirumuskan dalam kata-kata dan kalimat yang jelas.

4. Memberikan kesempatan yang cukup bagi debitur untuk mengetahui isi perjanjian.

Pada perspektif Undang-Undang

Perlindungan Konsumen (UUPK) dihubungkan dengan kasus posisi perkara perdata yang penulis teliti, maka point yang akan digarisbawahi adalah menyangkut penerapan asas perlindungan konsumen/Debitur, yaitu :

1) Asas Manfaat dalam hal ini baik pihak Kreditur maupun debitur memiliki kedudukan yang sama sehingga tidak ada kerugian dari masingmasing pihak dan dapat memperoleh haknya sebagai Kreditur serta Debitur.

2) Asas Keadilan merupakan asas yang paling sering dilanggar oleh suatu pihak, karena seharusnya dalam hal ini pelaku usaha (produsen) berlaku adil dalam menciptakan suatu barang/jasa baik dalam proses pembuatan serta dalam proses penentuan harga. Dengan rasa keadilan yang tinggi, maka tidak ada pihak yang merasa dirugikan dalam hal tersebut.

3) Asas keseimbangan merupakan asas dimana adanya keseimbangan antara kepentingan debitur maupun Kreditur serta pihak-pihak lain seperti pemerintah sehingga tercipta perekonomian yang baik dan stabil.

4) Asas keamanan dan keselamatan Debitur merupakan suatu asas dimana setiap barang/ jasa yang dihasilkan sudah memenuhi syarat untuk diproduksi dan disetujui oleh badan hukum yang berwenang sehingga produk yang ditawarkan dan dijual kepada konsumen layak untuk dikonsumsi karena dalam penggunaan barang/jasa oleh Debitur hal itu juga menyangkut atas keselamatan Debitur yang harus ditanggung oleh Kreditur maupun pemerintah jika terjadi suatu kecelakaan.

5) Asas kepastian hukum adalah asas yang membuat para pelaku usaha maupun Debitur dapat mematuhi peraturan yang berlaku sehingga tidak akan melanggar hukum yang telah diatur. Dengan adanya kepastian hukum maka Debitur juga dapat menggunakan produk/jasa dengan rasa aman dan dapat menjadi suatu jaminan apabila terjadi sesuatu yang tidak diinginkan dalam penggunaan produk/jasa tersebut. 
Selain itu terhadap aspek perbedaan persepsi antara Kreditur dan Debitur menyangkut kalkulasi / perhitungan sisa tunggakan kredit, perbedaan persepsi tentang jangka waktu kredit, serta keterlambatan dan ketertutupan atas informasi yang berhubungan dengan kontrak dalam perjanjian kreditnya dengan Kreditur menggambarkan adanya ketidaksesuaian terhadap pasal 3 UUPK point $d$ yang menekankan aspek perlindungan hukum dalam konteks kepastian hukun berkorelasi dengan keharusan adanya keterbukaan informasi dan kemudahan akses untuk mendapatkan informasi dari pihak Kreditur, sehingga keadaan dimana debitur merasa tidak paham, tidak mengerti, dan bingung dengan keadaan yang dialaminya bisa dihindari.

Sulitnya penyelesaian masalah kredit macet disebabkan beberapa faktor yang di antaranya bermula dari kurang diperhatikannya ketentuan-ketentuan yang berkaitan dengan hukum jaminan, khususnya dalam penggunaan tanah sebagai jaminan kredit. Sungguhpun tanah bukan merupakan satu-satunya jaminan, namun harus diakui bahwa tanah masih mempunyai nilai lebih bila dibandingkan dengan bentuk jaminan lainnya, hal ini karena tanah tidak mudah hilang atau rusak serta harganya cenderung meningkat, terutama tanah-tanah di daerah perkotaan. ${ }^{12}$

Mengingat telah mempunyai nilai ekonomis yang cukup tinggi, maka penggunaan tanah sebagai jaminan kredit dewasa ini di kalangan perbankan menempati prioritasnya / lebih diutamakan dibanding benda-benda jaminan lainnya.

Dalam kaitannya dengan Kreditur menjual atas kekuasaan sendiri melalui pelelangan umum obyek hak tanggungan apabila debitur cidera janji dan mengambil pelunasan piutangnya dari hasil penjualan tersebut, seharusnya tetap mempertimbangkan bahwa obyek hak tanggungan tersebut merupakan milik Debitur sebagai pemberi hak tanggungan sehingga pada saat dilakukan penjualan obyek hak tanggungan dalam lelang tetap berlandaskan kepada penghormatan kepada milik orang lain.

Pemahaman bahwa pihak pemberi Hak

12 Budi Harsono, "Upaya Badan Pertanahan Nasional Dalam Mempercepat Penyelesaian Kredit Macet Perbankan", Kumpulan Makalah dan Hasil Diskusi Panel I Sampai IV Pengurusan Piutang dan Lelang Negara, (Jakarta: Dep. Keu,. RI. BUPLN, 1998), hal. 400
Tanggungan adalah pihak selalu berkepentingan terhadap obyek hak tanggungan adalah penting sifatnya, karena bila terjadi penjualan obyek hak tanggungan pasti selalu ada harapan bahwa obyek hak tanggungan debitur bisa memberikan hasil penjualan yang tinggi.

Konsep penjualan jaminan melalui pelelangan umum ini sendiri sebenarnya bertujuan dengan harapan dapat diperoleh harga yang paling tinggi untuk objek hak tanggungan. Maka saat konsep pelelangan tersebut berimplikasi sebaliknya di lapangan, maka munculah banyak perkara yang berkaitan dengan lelang. Sesuai dengan asas kepatutan dan itikad baik, bank tidak menentukan sendiri harga jual atas barang-barang agunan dalam rangka penyelesaian kredit bermasalah debitur. Semestinya penaksiran harga obyek hak tanggungan terlebih dahulu dilakukan oleh suatu perusahaan penilai (appraisal company) yang independen dan telah mempunyai reputasi baik.

Perkara Gugatan Debitur itu sendiri inti pokok masalahnya adalah harga penjualan obyek hak tanggungan yang dinilai tidak wajar. Dalil yang dapat diajukan oleh penggugat adalah bahwa bank telah melakukan perbuatan melawan hukum atau bertentangan dengan kepatutan atau bertentangan dengan keadilan atau bertentangan dengan asas itikad baik terhadap harga penjualan obyek hak tanggungan yang dinilai tidak wajar. Dengan demikian maka sangat beralasan bila Asas kepatutan dan itikad baik serta asas penghormatan kepada milik orang lain dijadikan acuan Kreditur / bank dalam menentukan harga jual atas barang-barang agunan dalam rangka penyelesaian kredit bermasalah nasabah / debitur.

Aspek pentingnya Bank mempertimbangkan keadilan terhadap nilai jual obyek jaminan terlihat pula dalam kasus perkara di Pengadilan banding (Court of Appeal) yang secara aklamasi (unanimously) telah memutuskan bahwa di dalam melaksanakan kewenangannya untuk menjual barang agunan itu, tergugat dalam hal ini bank terikat pada kewajiban untuk mencapai harga yang sebenarnya (true value) dari properti itu. Hakim Salmon LJ mengemukakan bahwa :13 "accordingly conclude, both on principal

13 Adrian Sutedi, 2012, Hukum Hak Tanggungan, Sinar Grafika, Jakarta, hal. 142 
and auhority, that mortgagee in exercising his power of sale does owe a duty to take reasonable precaution to obtain the true market value of the mortgaged whether the has fallen short of that duty, $k$ the facts must be looked at broadly, and he will not be adjudged to be in default unless he is plainly on the wrong side of the line."

\section{Simpulan}

a. Peluang munculnya perlawanan debitur disebabkan karena perangkat perundangundangan yang dalam hal ini UUHT ternyata terkandung beberapa kelemahan yaitu : UUHT tidak mengatur tentang batasan definisi cidera janji, inkonsistensi antara Pasal 6 (hak menjual atas kekuasaan sendiri) dan Penjelasan Pasal 6 (hak menjual atas kekuasaan sendiri tetapi atas dasar perjanjian/ kesepakatan antara kreditur dengan debiturnya) sehingga menimbulkan peluang penafsiran yang berbeda dan Dualisme Lelang Eksekusi Hak Tanggungan : apakah bisa langsung dilakukan Lelang (sebagaimana irah-irah "Demi Keadilan Berdasarkan Ketuhanan YME dalam Sertifikat Hak Tanggungan) di Balai
Lelang atau harus melalui Fiat /Penetapan Pengadilan (sebagaimana Pasal 224 HIR yang mengatur tentang Parate Eksekusi).

b. Tanah merupakan jaminan kredit dengan nilai ekonomis yang tinggi, dan prioritas dibanding jaminan benda jaminan lain. Maka dengan pertimbangan bahwa obyek hak tanggungan itu merupakan milik debitur, untuk itu asas kepatutan, itikad baik dan penghormatan terhadap milik orang lain adalah sangat penting sifatnya bagi kreditur. Konsep lelang bertujuan untuk mendapatkan harga paling tinggi, namun dalam praktek terjadi kontraproduktif karena kreditur / bank menentukan secara sepihak nilai limit lelang obyek HT tersebut, sehingga harga jual lelang menjadi sangat tidak wajar dan ada potensi rekayasa lelang oleh "mafia lelang "yang telah menjadi rahasia umum, hal inilah faktor pemicu utama munculnya perlawanan dari debitur karena pada aspek ini debitur jelas dirugikan. Harga yang sebenarnya (true value) bisa didapat dengan pelibatan appraisal independent / penilai independen yang mempunyai reputasi baik dalam penentuan nilai limit lelang.

\section{Daftar Pustaka}

Ananda, C. Tinon Yunianti Drs., dkk, 1995, Dasar-dasar Perkreditan, PT. Gramedia Pustaka Utama, Jakarta

Arikunto Suharsimi, 2005 Manajemen Penelitian, Edisi revisi, Rineka Cipta, Jakarta,

Augustyas, Dhika, 2015 "Perlindungan Hukum Bagi Konsumen” diakses dalam https://dhiasitsme. wordpress.com/2012/04/18/perlindungan-hukum-bagi-konsumen/ pada tanggal $10 \mathrm{Mei}$ 2015 pukul 14.34 WIB

Badrulzaman, Mariam Darus, 2004, Buku II Kompilasi Hukum Jaminan, Mandar Maju, Bandung , 1997 Perjanjian Kredit Bank, PT. Citra Bakti, Bandung, 1991 2004 Kompilasi Hukum Jaminan, Buku II, Mandar Maju, Bandung

Djais, Moch. SH.,CN.,MHum, dan Suradi SH.,MHum, Kontrak (Pelatihan Kemahiran Hukum Kerjasama PT.PLN distribusi Jateng-Fakultas Hukum Universitas Diponegoro Semarang)

Djais, Mochammad, Peran sifat Accessoir Hak Tanggungan Dalam Mengatasi Kredit Macet, Badan Penerbit Undip, Semarang

Gatot, Wardoyo, dikutip dari M. Djumhana, 1992, Sekitar Klausul-klausul Perjanjian Kredit Bank, Bank dan Manajemen,

Harahap, M. Yahya, 1996, Perlawanan Terhadap Eksekusi Grose Akta Serta Putusan Pengadilan dan Arbitrase dan standar Hukum Eksekusi, Citra Aditya Bakti, Bandung

Harahap, M. Yahya, 2013, Ruang Lingkup Permasalahan Eksekusi Bidang Perdata, Edisi kedua : Sinar Grafika, Jakarta 
H. Salim HS, 2004, Perkembangan Hukum Jaminan di Indonesia PT. Radja Grafindo Persada, Jakarta

Harsono, Boedi, 2013, Hukum Agraria Indonesia, Sejarah Pembentukan Undang-Undang Pokok Agraria, Isi dan Pelaksanaannya, Edisi Revisi, Cetakan Kesembilan, Djambatan, Jakarta 1998 “Upaya Badan Pertanahan Nasional Dalam Mempercepat Penyelesaian Kredit Macet Perbankan", Kumpulan Makalah dan Hasil Diskusi Panel I Sampai IV Pengurusan Piutang dan Lelang Negara, Dep. Keu,. RI. BUPLN, Jakarta

Hernoko, Agus Yudha, 2010, Hukum Perjanjian;Asas Proporsionalitas dalam Kontrak Komersil, Prenadamedia Group, Jakarta

Indarti, Erlyn, 2010 Diskresi dan Paradigma : Sebuah Telaah Filsafat Hukum, Badan Penerbit Undip. Semarang

Isnaeni, Moch, Parate Executie Obyek Hak Tanggungan (Inkonsistensi, Konflik, Norma, dan Kesesatan Penalaran dalam UUHT), 2007, Cetakan I ; Laksbang Pressindo, Yogyakarta

Mertokusumo, Sudikno, 2011, "Mengenal Hukum, Suatu Pengantar", dalam Esmi Warassih "Pranata Hukum, Sebuah Telaah Sosiologis", Badan Penerbit Universitas Diponegoro Semarang

Michael, Groves, 1992, Managing Problem Loans, Tokyo: Bank Administration Institute

Muljadi, Kartini dan Widjaja, Gunawan, 2005, Seri Hukum Harta Kekayaan: Hak Tanggungan, Edisi Pertama, Cetakan Pertama, Kencana Prenada Media, Jakarta

Patrik Purwahid dan Kashadi, 2006, Hukum Jaminan edisi revisi dengan UUHT, Fakultas Hukum Undip, Semarang

Parlindungan,A.P., 1996, Komentar Undang-Undang tentang Hak Tanggungan, Cetakan Pertama, Mandar Maju, Bandung

Purbacaraka Purnadi dan Soekanto, Soerjono, 2011, "Perihal Kaidah Hukum" dalam Esmi Warassih "Pranata Hukum, Sebuah Telaah Sosiologis", Badan Penerbit Universitas Diponegoro Semarang

R.Subekti, KUH Perdata, Pradnya Paramita, Jakarta

Radbruch, Gustav, 2010 Einfuhrung in die Rechtswissenschaft, dalam Esmi Warassih "Pranata Hukum, Sebuah Telaah Sosiologis", Badan Penerbit Universitas Diponegoro Semarang

Rahardjo, Sutjipto, 2011 "Ilmu Hukum" dalam Esmi Warassih "Pranata Hukum, Sebuah Telaah Sosiologis", Badan Penerbit Universitas Diponegoro Semarang

Salim, Agus, 2006, Teori dan Paradigma Penelitian Sosial Buku Sumber Untuk Penelitian Kualitatif, Tiara Wacana, Jakarta

Satrio, J.,2002, Hukum Jaminan, Hak-Hak Jaminan Kebendaan, PT. Citra Aditya Bakti, Bandung Siswanto, Sutojo, 1995 Analisis Kredit Bank Umum, Pustaka Binaman Pressindo, Jakarta

Siswanto, Sutojo, 1996 Menangani Kredit Bermasalah, Pustaka Binaman Pressindo, Jakarta Sjahdeini, Sutan Remy, 1996, Hak Tanggungan, Asas-Asas, Ketentuan-Ketentuan Pokok dan Masalah-Masalah yang Dihadapi oleh Perbankan (Surabaya: Airlangga University Press, , 1993. Kebebasan Berkontrak dan Perlindungan yang Seimbang bagi Para Pihak

dalam Perjanjian Kredit Bank di Indonesia, Institut Bankir Indonesia, Jakarta

Soemitro, Ronny Hanitio, 2004, Metodologi Penelitian Hukum, Gahalia Indonesia, Jakarta

Soimin, Soedharyo, 2001 Status Hak dan Pembebasan Tanah Sinar Grafika, Jakarta

Suhartono, Irawan, 2004, Metode Penelitian Sosial Suatu Teknis Penelitian Bidang Kesejahteraan Sosial dan IImu Sosial, Remaja Rosdakarya, Bandung

Sumardjono, Maria, 1998, "Prinsip Dasar Hak Tanggungan Dan Beberapa Permasalahan Yang Berkaitan Dengan Kredit Perbankan”. Kumpulan Makalah Dan Hasil Diskusi Panel I sampai IV Pengurusan Piutang dan Lelang Negara,Dep. Keu. RI, BUPLN, Jakarta

Supramono, Gatot, 1995, Perbankan dan Masalah Kredit, Djambatan. Jakarta 
Sutedi, Adrian, 2012, Hukum Hak Tanggungan, Sinar Grafika, Jakarta

Sutrisno, Endang, 2013 Bunga Rampai Hukum dan Globalisasi, Penerbit In Media. Jakarta

Warassih, Esmi, 2011, Pranata Hukum, Sebuah Telaah Sosiologis, Badan Penerbit Universitas Diponegoro, Semarang

Widyadharma, Ignatius Ridwan, 1996, Undang-Undang Hak Tanggungan Atas Tanah Beserta Benda-Benda Yang Berkaitan Dengan Tanah, Cetakan Pertama, Badan Penerbit Universitas Diponegoro, Semarang

\section{Peraturan Perundang-Undangan :}

1. Undang-Undang No. 4 Tahun 1996 tentang Hak Tanggungan Atas Tanah Beserta BendaBenda Yang Berkaitan Dengan Tanah.

2. Undang Undang No.5 Tahun 1960 tentang Peraturan Dasar Pokok-pokok Agraria.

3. Undang Undang No. 7 Tahun 1992 tentang Perbankan dan UU No. 10 Tahun 1998 tentang Perubahan Undang Undang No. 7 Tahun 1992 tentang Perbankan.

4. Undang Undang No. 4 Tahun 1996 tentang Hak Tanggungan Atas Tanah Beserta BendaBenda Yang Berkaitan Dengan Tanah.

5. Undang-Undang No. 08 tahun 1999 tentang Perlindungan Konsumen.

6. Peraturan Bank Indonesia Nomor: 7/2/PBI/2005 tentang Penilaian Kualitas Aktiva Bank Umum.

7. Surat Edaran Bank Indonesia No. 26 / 4 / BPPP tgl 29 Mei 1993 tentang Penyelesaian Kredit Bermasalah Secara Administrasi Perkreditan.

8. Surat Keputusan Direksi Bank Indonesia No. 31 / 150 / KEP /DIR tgl 12 November 1998.

\section{Kamus Hukum :}

Black's Law Dictionary of Western Philosophy, Blackwell Publishing, 2004 